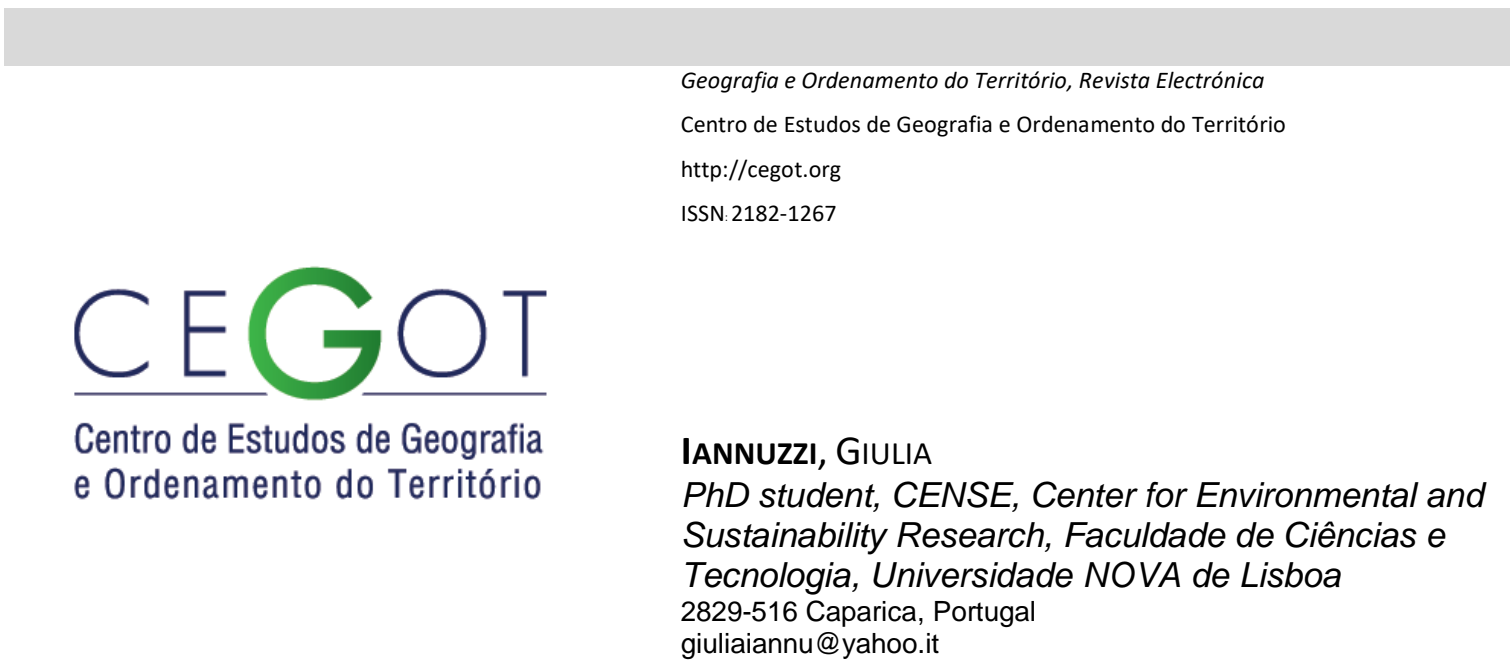

\title{
Private Protected Areas as policy instruments to tackle environmental challenges: discussing potentialities and pitfalls
}

\author{
As áreas protegidas privadas como instrumentos de política ambiental: \\ potencialidades e desafios
}

Referência: Iannuzzi, Giulia (2016). Private Protected Areas as policy instruments to tackle environmental challenges: discussing potentialities and pitfalls. Revista de Geografia e Ordenamento do Território (GOT), n.으 10 (dezembro). Centro de Estudos de Geografia e Ordenamento do Território, p. 189-206, dx.doi.org/10.17127/got/2016.10.009

\begin{abstract}
Protected Areas owned and managed by private actors are expected to have a relevant role in nature conservation policy as an additional tool to public-run protected sites. By reducing natural habitats destruction and degradation, well designed and well governed private protected areas (PPAs) can have a key role in tackling two intertwined global threats: biodiversity loss and climate change. In this article we will present PPAs diffusion in Europe basing on data collected from the European Common Database on Nationally Designated Areas. In addition, an assessment framework will be proposed, with the purpose of contributing to a broader understanding of PPAs potentialities and pitfalls. The main challenges for PPAs effectiveness deal with their geographical distribution and their ability to provide strong and stable legal structures for private protection, assuring adequate and inclusive governance.
\end{abstract}

Keywords: Nature conservation policy; private protected areas; climate change; biodiversity. 


\section{RESUMO}

As áreas protegidas geridas e de propriedade de agentes privados poderão vir a ter um papel relevante na política de conservação da natureza como ferramenta complementar às áreas implementadas e geridas por agentes públicos. Ao reduzir a destruição e a degradação dos habitats, as áreas protegidas privadas (APPs) bem desenhadas e reguladas podem auxiliar na luta contra duas ameaças globais: a perda da biodiversidade e as alterações climáticas. Neste artigo será apresentada a difusão APPs na Europa baseando-se em dados do Banco de Dados Europeu de áreas designadas (CDDA). Também será proposto um quadro analítico para discutir as potencialidades e os principais desafios das APPs, focando na distribuição geográfica e nos modelos de governança.

Palavras-chave: conservação da natureza, áreas protegidas privadas, mudanças climáticas, biodiversidade.

\section{Introduction}

Nature conservation strategies are increasingly reliant on market-based instruments, such as forest certifications and payments for ecosystem services, as well as on policy tools based on collaboration with private actors. Land purchases by NGOs for conservation management and conservation easements are also gaining momentum worldwide (Tikka, 2003).

Against this backdrop, the design and legal recognition of protected areas owned and managed by private actors is a response to growing concerns over biodiversity loss and the increasing awareness of the difficulty of the creation and maintenance of additional staterun nature reserves, due to the scarcity of public resources and competing priorities. It is widely acknowledged that in order to tackle biodiversity decline, relying on existing nature reserves run by public actors, which are the cornerstone of conservation strategies, might not be enough (Krug, 2001). Governments are required to meet their obligations under multilateral environmental agreements, in particular those defined by the Convention on Biological Diversity $(\mathrm{CBD})$ and the obligations under the EU nature conservation legislation which established the Natura 2000 network of protected sites. In particular the CBD Aichi target 11 states that by 2020, conserved areas should reach at least $17 \%$ for terrestrial areas (including inland water) and $10 \%$ for marine areas. Increasing the extension of effective protected areas is a challenging goal considering that lands having ecological features are 
often privately owned; for instance, in the United States ${ }^{1}$ more than $90 \%$ of endangered or threatened species have at least part of their habitat in private lands (Groves et al., 2000). In Portugal about the $93 \%$ of forest is privately owned (Feliciano et al., 2015).

The implementation of a protected area through imposed regulation on private lands usually cause physical, economic, and sociocultural displacement of local peoples from their lands and the reallocation of property rights (Mascia and Claus, 2009). These consequences may also be counterproductive for the management effectiveness if not coupled with the involvement of stakeholders and local communities (Hirschnitz-Garbers and Stoll-Kleemann, 2011). PPAs are seen as a more flexible tool than regulatory top-down approach. Indeed, in a PPA private landowners, NGOs or companies voluntarily limit human activities and resources uses negatively impacting biodiversity, and eventually implement active measures to promote nature conservation (Stolton et al., 2014). In sum, advocates of their diffusion underline PPAs ability in addressing conflicts and oppositions that arise when conservation measures entail limits on human action and economic development activities on privately owned land. Being voluntary instruments they do not entail a reallocation of property rights. Moreover, the involvement of private actors as managers of protected areas is considered to be a cheaper alternative in order to expand national networks of protected areas and thus meet the targets defined at international levels, reducing management costs on public budgeting. This is a powerful argument considering the severe public expenditure cuts that followed the financial and economic crisis. Moreover, private actors' financial resources as well as organizational resources and other skills are considered to hold great potentialities within the biodiversity conservation policy mix since private management structures can be particularly effective and efficient in capturing the economic values of biodiversity and ecosystem services.

In the last few decades, PPAs have increased worldwide (Borrini-Feyerabend et al., 2013), especially thanks to the eco-tourism boom (Langholz, 2010). Nevertheless, PPAs diffusion in terms of number and area extension, is largely un-documented as well as their governance settings and their outcomes. A growing number of scholars (Langholz et al., 2000; Holmes, 2013) recognizes PPAs potentialities as an additional tool, rather than a substitute to other

\footnotetext{
${ }^{1}$ It is important to specify that the country has not yet ratified the Convention on Biological Diversity.
} 
forms of protected areas, within nature conservation policies whose main goals are to reduce biodiversity loss and preserve cultural and esthetic values central to human-nature relationships. The purpose of the establishment of a protected area, publicly or privatelyrun, is to provide a wide spectrum of ecological and social benefits; additionally, it is "sometimes expected to serve as a motor for regional development" (Hammer, 2007: 28) especially when created in peripheral rural areas, through tourism-related revenues.

In order to gain a broader perspective, research aiming to carefully investigate PPAs potentials and limitations should bear in mind three key points: i) firstly, as outlined above, PPAs can contribute to several goals and objectives and their implementation is expected to generate multiple outcomes; ii) secondly, positive as well as negative synergies may occur between the identified objectives, also depending on temporal scale (short-term or long term objectives); iii) lastly, PPAs should be addressed and investigated as part of a policy portfolio defined as a mix of approaches and strategies that can fulfill the divergent goals of policy decision, profiting from synergies while reducing the risk of failure (Doremus, 2003).

The article's aim is twofold: i) analysing PPAs diffusion in Europe considering data provided by the European Common Database on Nationally Designated Areas; ii) proposing a preliminary assessment framework with the purpose of contributing to a more comprehensive understanding of PPAs' role in climate change and nature conservation policies. Despite the growing interest in PPAs and their promotion, as demonstrated by the increasing number of reports - IUCN has recently published a report on private protected areas (see Stolton et al., 2014) and the European LIFE programme has commissioned the study "Alternative Ways to Support Private Land Conservation" (Disselhoff, 2015) - policy makers should not see PPAs as the most cost-effective tool to expand protected area network without evaluating their weaknesses, whether they are structural or contextsensitive. Most of the potentialities and challenges discussed hereafter are specific to PPAs, however some of them apply to protected areas in general. 


\section{Private Protected Areas in Europe}

\subsection{Method}

The IUCN (Borrini-Feyerabend, 2013) has proposed an international system for categorising protected areas. Here, four governance typologies are distinguished: i) protected areas managed by public authorities (the most common type), ii) co-managed protected areas, iii) community-conserved areas, owned and managed by indigenous people and local communities, iv) PPAs. Nevertheless, it is not always easy to assign a governance type since some features belonging to different categories may overlap. In this sense and according to IUCN's definition that is used for the purposes of this article, PPAs are:

clearly defined geographical space, recognised, dedicated and managed, through legal or other effective means, to achieve the long-term conservation of nature with associated ecosystem services and cultural values" (Dudley, 2008: 8), "under individual, cooperative, NGO or corporate control and/or ownership, and managed under not-for-profit or for-profit schemes[...](where) the authority for managing the protected land and resources rests with the landowners, who determine the conservation objective, develop and enforce management plans and remain in charge of decisions, subject to applicable legislation. (Dudley, 2008: 26).

Despite growing evidence, the diffusion of PPAs is still relatively neglected, especially in Europe where public sector has been a traditional focus of study since state-run protected areas reflect the most common governance typology (Holmes, 2013). An additional explanation is that data on PPAs are less readily available to researchers.

In order to provide an overview of the diffusion of PPAs included within national protected area networks in the European Union member states, data have been collected from the European Common Database on Nationally Designated Areas (CDDA), version 13. It is a database maintained for the European Environmental Agency (EEA) by the European Topic Center on Biological Diversity, holding data and information about protected sites and national legislative instruments that create and regulate protected areas ${ }^{2}$.

\footnotetext{
${ }^{2}$ CCDA covers the entire geographical area of the countries that make up the EEA corresponding to 39 countries including Greenland (Denmark) and the French Overseas Departments and Territories, and Overseas Collectives. Available on-line at: http://www.eea.europa.eu/data-and-maps/data/nationally-designated-areasnational-cdda-10.
} 
Data registered in the CDDA have been collected and analysed in order to describe the diffusion of PPAs in Europe in terms of total number and covered areas. In particular, for each of the EU member states we collected data on PPAs legally recognized and regulated as a specific category of protected areas; that is, protected sites with private statute providing durable protection for flora, fauna and habitats.

\subsection{PPAs diffusion in Europe}

PPAs are not a recently born governance type of protected areas, though their earlier forms were primarily aimed at excluding commoners and preventing peasants from using resources rather than conservation measures per se (Weddel, 2002). However, the last decades have witnessed PPAs proliferation and the emerging of policy and legal frameworks for PPAs, with the United States, Australia, Brazil and Costa Rica among some of the early innovator countries (Langholz, 2010).

Focusing on the European Union, Graphic n.1 and Graphic n.2 show that four countries have already a list of legally recognized PPAs integrated in the national network of protected areas: Finland, France, the Netherlands and Portugal.

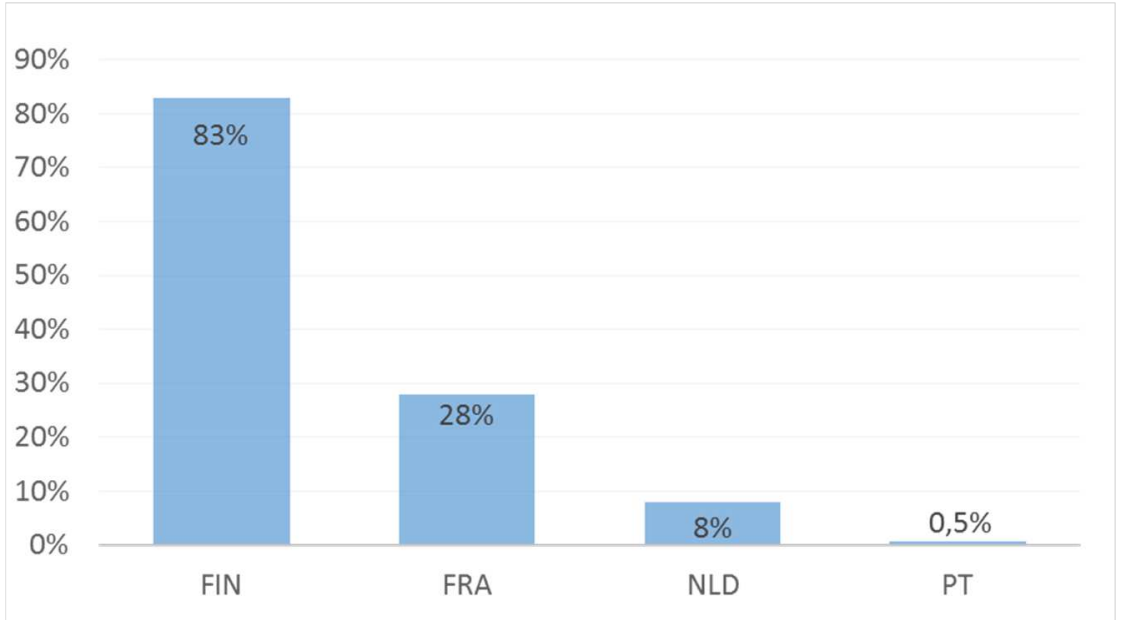

Graphic n.1 PPAs percentage of total protected areas Source: CDDA, version 13. 


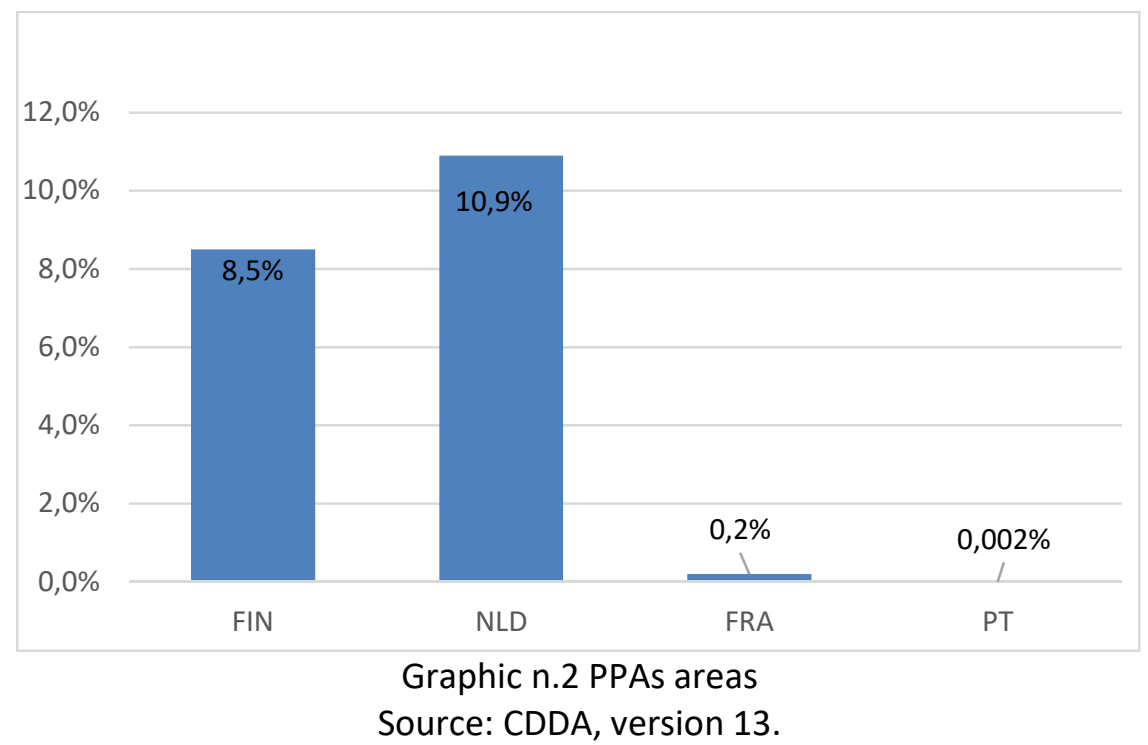

The case of Finland is significant with more than the $80 \%$ of the protected areas included in its national network, owned and managed by private actors, corresponding to roughly the $8 \%$ of the total area under protection. These records are explained by the impact of the successful implementation of the Metso Programme (2008-2016) launched by the Ministry of the Environment, the Ministry of Agriculture and Forestry, the Finnish Environment Institute and the Forest Development Centre Tapio, in order to tackle the biodiversity decline in forest habitats. The public-led programme aims at activating voluntary-based conservation agreements between forest owners and public authorities through a payment for ecosystem services mechanism. Between 2000 and 2010 some 5.600 new PPAs were established in Southern Finland under the Metso program and since 2005, 81 million euros have been allocated to PPAs' landowners as compensation for income loss (Stolton et al., 2014).

PPAs in France correspond to $28 \%$ of the total natural reserves; these are natural reserves owned and managed by the Natural Areas Conservation Society (Conservatoire des espaces naturels- CEN). CENs are part of a NGOs national federation, representing them at national level and providing technical support. This is the only NGO whose role is officially recognized by the national Environmental Code since 2010. CENs can both own and rent the land, or enter into management agreements with public or private entities (Guigner and Prieur, 2010). 
In the Netherlands, civil society and private actors have had a key role in the purchase and management of rural areas for conservation purposes. The major landowning nature protection organization, Natuurmonumenten, was created in 1905 and two private National Parks were established in the 1930s. Government intervention followed later on with legislation protecting private estates (Elbersen, 2001), while the designation of further National Parks only starts from the 1980s. In addition to the National Parks registered in CDDA as having a private statute (two of them are privately owned and managed, the others managed through co-governance approaches), we should consider sites recognized and brought under the Nature Conservation Act in 1968 as nature reserves, which are owned and/or managed by private organizations and public bodies (ibidem). More recently, starting from 1990, the Dutch National Ecological Network of protected areas (NEN) has been designed through a systematic planning; private actors, such as nature preservation organizations, have been involved in NEN areas management, receiving subsidies from provincial governments for land acquisitions(Bakker et al., 2015).

In Portugal the Faia Brava Reserve, owned and managed by a NGO, was legally recognized in 2010 as the first national private protected area within a specific legal framework. Precisely, the Decree-Law n. 142/2008, regarding nature and biodiversity conservation, states that a private land that is not included in classified natural sites may be given the designation of private protected area and integrated in the national network of protected areas. In case of recognition, a binding management plan will be agreed with the national authority (Instituto da Conservação da Natureza e das Florestas, ICNF). The application process and recognition of PPAs was established a year later with Portaria n. 1181/2009. It requires that the designation of a PPA can be requested by the owner(s) of properties in the area, as well as a different right-holder that the owners have authorized for that purpose, or by environmental NGOs or legal entities under private law the owner(s) have concluded an agreement with for the submission of the application. Conservation activities planned for the area management must comply with the objectives stated by national laws.

It is important to note that PPAs have emerged in European countries with a traditional public conservation policy based on public actors management of natural reserves (e.g. Portugal, France) or public ownership. A preliminary document and literature review on 
national legal and institutional frameworks for PPAs indicated that, excluding the Finnish Metso initiative, a public-led program addressing private landowners, no-profit actors (e.g. environmental NGOs) are the most common typology of private actors currently owning and managing European PPAs integrated in national networks of protected areas. However, for profit actors are not always excluded as potential PPAs' owners, that is the case for example of the Portuguese legislative framework.

Despite specific country experiences outlined above, if we consider PPAs recognized as a policy instrument, their extension and contribution to the total of protected areas at European level appear to be still minor. Nevertheless, it is worth highlighting that beyond formally recognized PPAs other models and experience of protected areas managed by nonstate actors exist, however they have received little scholars' attention.

\section{Private Protected Areas role in addressing environmental challenges}

\subsection{Introductory considerations}

Discussion on PPAs contribution to nature conservation policies should explore their distribution amongst biomes and endangered habitats. It should be focused on their outcomes as buffer zones and as relevant stepping stones for biological continuum within the network of public-run natural reserves (Langholz and Lassoie: 2001). This especially applies, in order to ensure cost-effective actions, when public resources are used to incentivize the involvement of private landowners or NGOs as managers. Also, as regards Natura 2000 network, "biodiversity conservation" is the prevailing management philosophy applying the notion of biodiversity representativeness to select priority areas. In addition, in order to facilitate migration of species in response to climate change and decrease extinction risk, several European governments have already committed themselves to the design and implementation of national ecological networks (Bakker et al. 2015).

By reducing ecosystem destruction and degradation, protected areas may have a key role in climate change mitigation and adaptation. They reduce greenhouse gas emissions and 
maintain ecosystem processes and services they provide, which are essential for society to cope with the impacts of natural disasters and other effects of climate change, thus increasing resilience and reducing both communities' and ecological systems' vulnerability.

National and international strategies tackling climate change are not entirely recognizing the mitigation and adaptation potential of protected areas on global and local scale, and this could cause a failure in successfully integrating nature conservation policy with climate change protocols. Due to the significant overlap between the drivers of climate change and the drivers of biodiversity loss, it is crucial that the two work in synergy.

Additionally, we must carefully take into account the other side of the coin, that is the challenges arisen by climate change effects on the reserves management and on national and international protected-area planning system. Climate change is already disrupting ecological relationships, species ranges and interactions (Stein et al., 2014). Impacts are expected to increase over time, pushing ecosystems towards ecological thresholds and transition. On one hand, protected sites are less stressed by non-climate-related pressures with healthier ecosystems and biological diversity, thus more resilient to disturbance (Elmqvist et al., 2003); on the other hand, policy makers and site managers are being confronting with uncertainty in climate change projections, impacts magnitude and in the evaluation of the sites and networks' vulnerability. The relevance of these threats and the urgency of effective strategies and implementation of useful adaptation and mitigation measures is also reflecting in their significant place on the international agenda; in particular, the IUCN World Commission on Protected Areas is currently developing a guidebook titled Responding to Climate Change: Guidance for Protected Area Managers and Planners which especially focuses on adaptation strategies for protected areas in the face of climate change, stressing upon the need of monitoring both vulnerability assessment and adaptive management approaches.

Considering our focus on the potential role of a specific governance type of protected areas (PPAs) in addressing biodiversity loss and climate change, two facets concerning its peculiarities must be acknowledged. Firstly, issues may arise when protected areas, shaped in order to provide public outcomes, are owned and managed by private actors. Specific concerns are related to accountability and transparency principles. Moreover, some 
questions have been raised about the commodification and neo-liberalization of nature (Castree, 2003) especially when in protected areas ecotourism activities are allowed, that in the case of PPAs, may be the main source of revenues. As argued by Langholz and Lassoie (2001; 1081) an "insidious shortcoming is the potential conflict of interest between ecology and economics. Those reserve owners dependent on tourism may be tempted to degrade resources rather than conserve them, placing profit over protection." Secondly, since PPAs are voluntarily provided and created by landowners, ONGs, land-trusts or private companies, even if a legal recognition is required, we assume that a prioritization on national level of localization is more difficult to occur, especially when not supported by a consistent national strategic plan. However, this concern is not entirely distinctive of PPAs since global protected area estate was found to be biased towards locations that are cheaper to protect and away from important areas for biodiversity conservations, adequately covering just the $15 \%$ of threatened vertebrates (Venter et al., 2014).

\subsection{Private Protected areas key contributions to enhancing climate change mitigation and adaptation}

By ensuring the conservation of the ecosystems, protected areas, regardless of the governance type, reduce emission of carbon dioxide from land use change, specifically avoiding the loss of stored carbon that would otherwise be released in the atmosphere. Therefore, they serve as an important carbon pool; according to Campbell's estimates, the current global system of protected areas stores roughly 312 gigatonnes of terrestrial carbon (Campbell et al., 2008). UNEP-WCMC estimated that protected areas carbon store amounts to the $15 \%$ of the terrestrial carbon stock (Stolton et al., 2014). This role is evidenced by the international efforts made to promote the protection of the tropical forests through the REDD programme (especially in developing countries), reducing in this way part of the emissions coming from deforestation and forest degradation. Grasslands, inland waters and marine biomes are also important carbon reservoirs. Additionally, active measures of afforestation, reforestation and restoration of natural habitats that expand carbon pools allow carbon sequestration. 
The adaptation role of protected areas, concerning adjustments in natural and human systems in response to actual or expected climate and its effects, can be described using an ecosystem-based approach. Enhancing and expanding protected and well managed ecosystems can buffer human communities against natural disasters through risks' reduction (maintaining mechanisms of flood controls, for instance). Moreover, the delivery of ecosystem services can help people coping with the negative impacts of climate change supplying human needs (e.g. water and food supply). In turn, facing the increasing pressure on biodiversity, the reduction of "non-climate" threats can be seen as a relevant adaptation approach.

Another potential key contribution is related to public and stakeholders' involvement and local communities' participation in protected area management, which is commonly referred as a condition for enhancing communities' adaptive capacity. However, a growing number of scholars have warned about the challenges that public participation could pose, especially in the case of anticipatory responses to climate change that present a high degree of uncertainty (Few et al., 2006).

Giving their peculiarities, how could PPAs mitigate climate change, address biodiversity loss, and help people adapt to their impacts? As a complementary tool for nature conservation, PPAs expand the coverage of protected area networks thus allowing positive outcomes related to the permanence of carbon pools, that keep carbon stored, and to the adaptation's measures presented in Table n.1.

Furthermore, PPAs can foster the ecological resilience to climate change of national and European protected areas networks enhancing connectivity that facilitate the movement of some species between protected areas. This would increase the network's resilience to climate related threats while simultaneously delivering societal benefits, namely reducing vulnerability in face of extreme weather events and other impacts. Focusing on the dimension of the ecological systems, PPAs' creation can be seen as a relevant strategy, especially if we take in account that climate change will affect species range dynamics. This fact makes it necessary to reconsider the current fixed networks of protected areas; nevertheless, in order to be effective the design of future systems of protected areas (including new PPAs) need to consider the strategic location of each protected site. 
Therefore, the chance of ensuring ecological integrity of natural habitats and related ecosystem processes is a key contribution of PPAs that can provide positive effects within a well-designed nature conservation strategy with climate-informed goals.

\begin{tabular}{|l|l|}
\hline PPAs main potentialities & PPAs key challenges \\
\hline $\begin{array}{l}\text { Expansion of protected area network in the } \\
\text { context of limited public conservation } \\
\text { resources }\end{array}$ & $\begin{array}{l}\text { PPAs location and effective contribution to } \\
\text { coverage of threatened species, ecosystem } \\
\text { services and habitats }\end{array}$ \\
\hline $\begin{array}{l}\text { Reduction of ecosystems' destruction and } \\
\text { degradation, (reducing drivers of climate } \\
\text { change) }\end{array}$ & $\begin{array}{l}\text { Governance model adopted considering their } \\
\text { ability to reconcile public and private } \\
\text { interests and accountability, transparency, } \\
\text { participation issues }\end{array}$ \\
\hline $\begin{array}{l}\text { Maintenance of ecosystem processes and } \\
\text { services essential for natural hazard risk } \\
\text { reduction and for society to cope with the } \\
\text { impacts of natural disasters and other effects } \\
\text { of climate change (reducing natural hazard } \\
\text { risks and communities' vulnerability) }\end{array}$ & $\begin{array}{l}\text { Sustainability: long term } \\
\text { and long term protection }\end{array}$ \\
\hline $\begin{array}{l}\text { Empowerment of private landowners } \\
\text { through participation process (increasing } \\
\text { resilience and adaptive capacity) }\end{array}$ & \\
\hline
\end{tabular}

Table n.1 PPAs potentialities and challenges in addressing biodiversity loss and climate change

Another important key contribution refers to PPAs potential in building people's resilience capacity in the face of climate vulnerability. PPAs are considered to be a more flexible tool than state-run protected areas since legal protection with conservation objectives is not imposed in privately owned land through a top-down approach. Conversely, it is the private actor that voluntarily imposes some limits on human activities. Therefore, on one hand it seems that a reduced social controversy could be a relevant aspect to allow a growing participation of local communities in the management of the protected site. On the other hand, it is worth noting that the governance model adopted by each PPA and the institutional and socio-economic context are critical determinants for institutions and local communities' adaptive capacity building.

\subsection{A preliminary assessment framework}

As argued above, a discussion on PPAs' contribution to environmental challenges should explore their strategically planned location and their management effectiveness. More in 
details, as shown in figure n.1, there is a need to assess PPAs distribution amongst biomes and their representation of key ecosystem services for global warming and climate change fight, such as carbon storage. Moreover, it is critical to better understand PPAs' location in relation to state reserves and other classified areas in national and international networks, their distribution as buffer zones and as stepping stones for the creation of a biological continuum that links pre-existing protected areas.

Additionally, assessment of good governance principles that are recognized in the academic literature as a prerequisite for effective management in protected areas and the embodiment of democratic and participatory traditions rooted in public interest are needed (Hannah, 2006). This is particularly urgent if we consider the raising concerns over the process of neoliberalization of environmental governance and the trend toward the withdrawal of public sector from the management of public goods that can be detected in the shifting from state responsibility on protected area establishment and management to an increasing private sector involvement in nature conservation policies.

While management effectiveness assessment is well established, protected areas governance assessment is a comparatively recent development. Protected areas governance quality evaluation frameworks have been proposed by IUCN (Borrini-Feyerabend, 2013) and Lockwood (Lockwood, 2010) building on the principles suggested by Graham et al. (Graham et al., 2013): legitimacy and voice, direction, performance, accountability and fairness. Adaptations of those frameworks to make them more suitable for the peculiarities of PPAs in Europe are therefore required.

Moreover, it would be worthwhile to investigate PPAs' protected status, focusing on the characteristics of the conservation agreement and government-approved management plan of the single PPA with a particular attention to the implications related to its ability to secure biodiversity conservation in the long term. While empirical studies have explored state protected areas downgrading, downsizing, and degazettement mainly caused by access to natural resources (Mascia et al., 2014), no comprehensive study has been made yet on PPAs financial sustainability, particularly relevant in the case of PPAs dependency on ecotourism trends. 


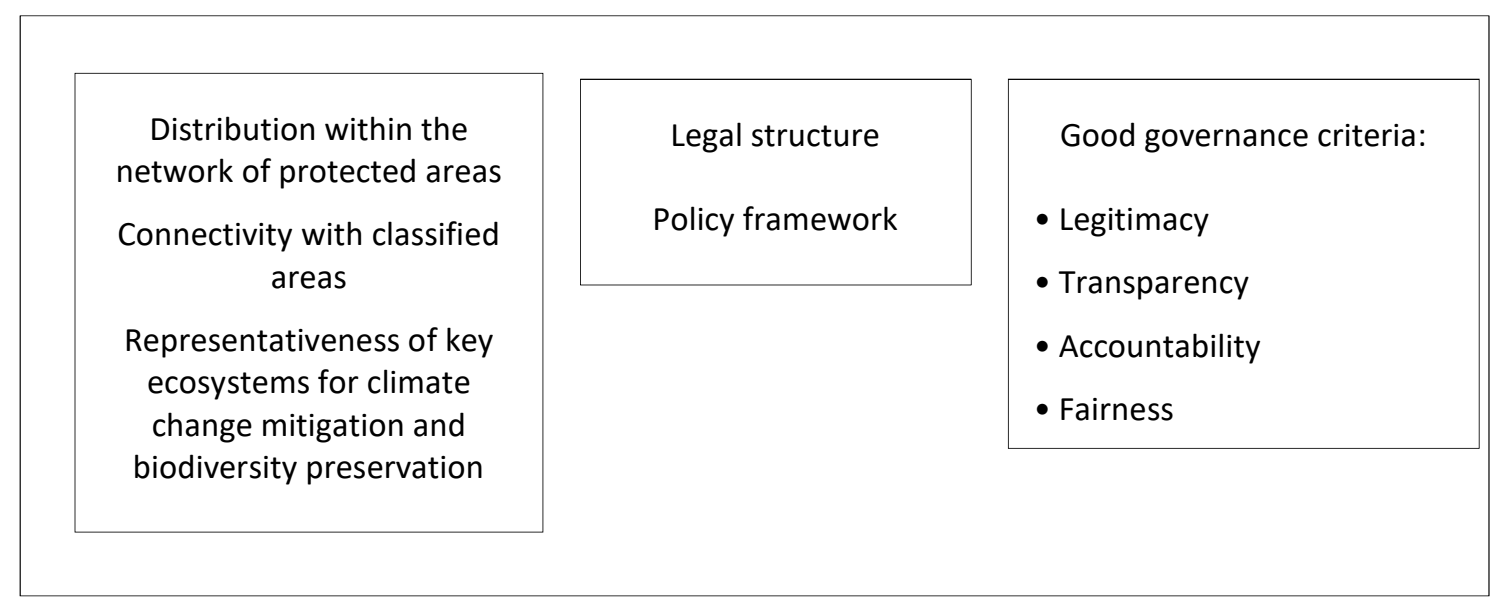

Figure n. 1 The assessment framework

\section{Concluding remarks}

National parks, natural reserve and other management typologies of protected areas are recognized as the core of nature conservation policies efforts in Europe and worldwide, covering $15.4 \%$ of the terrestrial and inland water areas and $8.4 \%$ of the marine area (JuffeBignoli et al., 2014). The current and expected impacts of climate change could give protected areas a renewed role. Protected areas, regardless of their management and governance type are able to tackle two intertwined global threats: biodiversity loss and climate change.

Data analysis from the European Common Database on Nationally Designated Areas shows that State protected areas are the cornerstone of European protected area network. Nevertheless, the characteristics of some protected areas which are owned and managed by private actors, as discussed above, could turn PPAs in a relevant and promising instrument for expanding nature conservation areas, particularly considering the importance given by the Biodiversity Strategy to 2020 of the European Union (European Commission, 2011) on private sector involvement and public-private partnerships to halt the loss of biodiversity. Concurrently, as already mentioned, the Parties to the Convention on Biological Diversity agreed on Aichi target 11 which states that conserved areas should reach at least $17 \%$ for terrestrial areas (including inland water) and 10\% for marine areas. Increasing the amount 
of protected sites is an ambitious goal, it is as well as the real issue at stake is the design and implementation of effectively managed and well-governed new protected areas able to deliver biodiversity conservation outcomes and provide societal benefits.

In particular, the main challenges for PPAs effectiveness in addressing biodiversity loss and climate change are related to their geographical distribution, connectivity, and representativeness and their ability to provide strong and stable legal structures for private protection. Securing accountability and effective participation is crucial to ensure adequate and inclusive governance. Therefore, research is required on opportunities and tradeoffs between mitigation and adaptation measures and biodiversity conservation in PPAs as well as on related policy and legal frameworks for PPAs. Governance assessment is also necessary. Furthermore, this investigation should be undertaken within a broader discussion on why, for whom and how nature conservation should be performed. The fact that some EU countries have recently developed regulation and legislation for PPAs explains the research relevance also in view of monitoring activities.

\section{Acknowledgements}

My thanks go to my supervisors, Prof. Rui Santos and Dr. João Mourato and to the two reviewers for their valuable comments. The author acknowledges the financial support of Fundação para a Ciência e Tecnologia through the scholarship PD/BD/106025/2014

\section{References}

BAKKER, M., ALAM, S.J., DIJK, J. VAN, ROUNSEVELL, M., SPEK, T., BRINK, A. van den. The feasibility of implementing an ecological network in The Netherlands under conditions of global change. Landscape Ecology 30, 791-804. (2015) doi:10.1007/s10980-014-0145-5

BORRINI-FEYERABEND, G., DUDLEY, N., JAEGER, T., LASSEN, B., PATHAK BROOME, N., PHILLIPS, A. and SANDWITH, T. Governance of Protected Areas: from understanding to action. Best Practice Protected Area, Guidelines Series No. 20, Gland, Switzerland, IUCN, (2013).

CAMPBELL, A., MILES, L., LYSENKO, I., HUGHES, A., GIBBS, H. Carbon storage in protected areas: technical report. UNEP - World Conservation Monitoring Centre, Cambridge, UK. (2008). 
CASTREE, N. Neoliberalism and the biophysical environment 2: theorising the neoliberalisation of nature. Geography Compass, 4(12):1734-1746. (2010) DOI: 10.1111/j.1749-8198.2010.00407.x

DISSELHOFF, T. Alternative ways to support private land conservation. Natura 2000, LIFE Programme, (2015).

DOREMUS, H. A Policy Portfolio Approach to Biodiversity Protection on Private Land. Environmental Science and Policy, 6: 217-232, (2003). DOI: 10.1016/S1462-9011(03)00036-4

DUDLEY, N. Guidelines for applying protected area management categories IUCN. Gland, Switzerland, (2008).

ELBERSEN, B. Nature on the doorstep: the relationship between protected natural areas and residential activity in the European countryside. Alterra, Utrecht/Wageningen, The Netherlands. (2001)

ELMQVIST, T. CARL FOLKE, C., NYSTRÖM, M., PETERSON, G., BENGTSSON, J., WALKER, B., JON NORBERG, J., Response Diversity, Ecosystem Change, and Resilience. Frontiers in Ecology and the Environment, 1(9):488-494. (2003).

European Commission, Our life insurance, our natural capital: an EU biodiversity strategy to 2020. COM (2011), Brussels. (2011).

FELICIANO, D., ALVES, R., CARVALHO MENDES, A., RIBEIRO, M., SOTTOMAYOR, M., Forest Land Ownership Change in Portugal. COST Action FP1201 FACESMAP Country Report, European Forest Institute Central-East and South-East European Regional Office, Vienna. (2015)

FEW, R., BROWN, K., TOMPKINS, E.L. Public participation and climate change adaptation. Tyndall Centre Working paper 95, (2006).

GRAHAM, J., AMOS, B., PLUMPTRE, T. Governance principles for protected areas in the 21st century, a discussion paper. Institute on Governance in collaboration with Parks Canada and Canadian International Development Agency, Ottawa. (2003).

GROVES, C.R., KUTNER, L.S., STOMS, D.M., MURRAY, M.P., SCOTT, J.M., SCHAFALE, M., WEAKLEY, A.S., PRESSEY, R.L. Owning up to our responsibilities: who owns lands important for biodiversity. In: Stein, B.A., Kutner, L.S., Adams, J.S. (Eds.) Precious Heritage: The Status of Biodiversity in the United States. Oxford University Press, New York, (2000).

GUIGNER, A. and PRIEUR, M. Legal Framework for Protected Areas: France. IUCN-EPLP 81 (2010).

HAMMER, T. Protected areas and regional development: conflicts and opportunities. In Protected areas and regional development in Europe. Towards a new model for the 21st century. Ashgate, Hampshire, 21-36, (2007).

HANNAH, L. Governance of private protected areas in Canada: Advancing the public interest? PhD Thesis. Department of Geography. University of Victoria, Victoria, Canada, (2006).

HIRSCHNITZ-GARBERS, M. and STOLL-KLEEMANN, S. Opportunities and barriers in the implementation of protected area management. A qualitative meta-analysis of case studies from European protected areas. The Geographical Journal 177 (4): 321-334, (2011).

HOLMES, G., What role do private protected areas have in conserving global biodiversity?, SRI working papers (46), (2013).

JUFFE-BIGNOLI, D., BURGESS, N.D., BINGHAM, H., BELLE, E.M.S., DE LIMA, M.G., DEGUIGNET, M., BERTZKY, B., MILAM, A.N., MARTINEZ-LOPEZ, J., LEWIS, E., EASSOM, A., WICANDER, S., GELDMANN, J., VAN SOESBERGEN, A., ARNELL, A.P., O'CONNOR, B., PARK, S., SHI, Y.N., DANKS, F.S., MACSHARRY, B., KINGSTON, N. Protected Planet Report 2014. UNEP-WCMC: Cambridge, UK. (2014).

KRUG, W. Private Supply of Protected Land in Southern Africa: a review of markets, approaches, barriers and issues. World Bank / OECD International Workshop on Market Creation for Biodiversity Products and Services, Paris, (2001).

LANGHOLZ, J., LASSOIE, J. P., LEE, D., CHAPMAN, D. Economic considerations of privately owned parks, Ecological Economics, 33, (2), 173-183, (2000). DOI: 10.1016/S0921-8009(99)00141-X 
LANGHOLZ, J., LASSOIE, J. Perils and promise of privately owned protected areas. Bioscience, 51:1079-1085, (2001).

LANGHOLZ, J. Global Trends in Private Protected Areas and their implications for the Northern Great Plains. Great Plains Research 20, (1): 9-16, (2010).

LOCKWOOD, M. Good governance for terrestrial protected areas: A framework, principles and performance outcomes, Journal of Environmental Management, 91, (3): 754-766, (2010).

MASCIA, M. and CLAUS, C.A. A property rights approach to understanding human displacement from protected areas: the case of marine protected areas. Conservation Biology 23(1):16-23, (2009).

MASCIA, M.B., PAILLER, S., KRITHIVASAN, R., ROSHCHANKA, V., BURNS, D., MLOTHA, M.J., MURRAY, D.R. and PENG, N. Protected area downgrading, downsizing, and degazettement (PADDD) in Africa, Asia, and Latin America and the Caribbean, 1900-2010. Biological Conservation 169: 355-361, (2014).

STEIN, B.A., GLICK, P., EDELSON, N., STAUDT, A. (eds.), Climate-smart conservation: putting adaptation principles into practice. National Wildlife Federation, Washington, D.C. (2014).

STOLTON, S., REDFORD, K.H., DUDLEY, N. The futures of Privately Protected Areas. IUCN: Gland, Switzerland (2014).

TIKKA, P. Conservation contracts in habitat protection in southern Finland. Environmental Science and Policy 6 (3) 271-278, (2003). DOI: 10.1016/S1462-9011(03)00045-5

VENTER, O., FULLER, R.A., SEGAN, D.B, CARWARDINE, J., BROOKS, T., BUTCHART, S.H.M., DI MARCO, M., IWAMURA, T., JOSEPH, L., O'GRADY, D., POSSINGHAM, H.P., RONDININI, C., SMITH, R.J., VENTER, M., WATSON, J.E.M. Targeting Global Protected Area Expansion for Imperiled Biodiversity. PLoS Biology 12(6): e1001891. (2014)

WEDDELL, B. J. Conserving living natural resources: in the context of a changing world. Cambridge University Press, Cambridge. (2002) 